\title{
Improvement of methodological support of internal control in the cash management system of the enterprise
}

\author{
Alsou Zakirova ${ }^{1, *}$, Guzaliya $\mathrm{Klychova}^{1}$, Svetlana Doronina ${ }^{2}$, Olga $V$. Abasheva ${ }^{2}$, and \\ Nuriya Nigmatullina ${ }^{1}$ \\ ${ }^{1}$ Kazan State Agrarian University, 65, Karl Marx str., 420015, Kazan, Russia \\ ${ }^{2}$ Izhevsk State Agricultural Academy, 11, Studencheskaya str., 426069, Izhevsk, Russia
}

\begin{abstract}
Currently, most business operations conducted by an economic entity, including the implementation of settlements with counterparties, associated with the movement of cash flows. Consequently, of particular relevance acquired questions implementation of internal control, which contributes to information and advisory support and optimization of financial and economic activities of the enterprise. The purpose of the article is to develop the system of methodological support of internal control of funds at the enterprise. In article theoretical bases of realization of control procedures are studied. The basic principles, the purpose and methods of internal control of funds are defined. For the development of methodological tools it is suggested to use the developed forms of working documents of internal control. These documents allow to systematize control measures, to evaluate the efficiency of accounting system organization, to generalize the results of cash and bank account transactions inspection, their appropriateness and validity; to record the revealed violations by the results of cash and bank account transactions inspection. Based on the results of internal control, the company's management makes a decision to improve the efficiency of cash usage based on the creation of a liquidity management system.
\end{abstract}

\section{Introduction}

In today's environment, cash is one of the main assets that ensure the financial wellbeing of enterprises that interact with counterparties by carrying out cash and non-cash settlements [1-3].

If an enterprise lacks the minimum necessary reserve of monetary resources, it means that the enterprise has serious financial problems. At the same time, if the enterprise has excessive cash, it means that there is a probability of their impairment and inflation, and there is a missed opportunity to obtain additional income and to place them profitably [4-6].

Cash is a current asset, which has absolute liquidity, that is, it can immediately act as a means of payment for the existing obligations of the enterprise. The volume of cash and the speed of its movement determine liquidity, solvency and affect the efficiency of financial

\footnotetext{
* Corresponding author: zakirovaar@mail.ru
} 
and economic activities of the enterprise [7-9].

The cash management system implies optimal planning of their movement so that the enterprise could timely repay its obligations at the expense of cash received from buyers, while maintaining a certain amount of reserve [10-12]. Thus, enterprises can maintain operational solvency, extract additional profits by investing free cash in business expansion [13].

In an unstable economic situation, cash is the enterprise's asset, which is a measure of value, a way of exchange and accumulation of capital and ensures the implementation of the strategic goals of the enterprise $[14,15]$. The absolute liquidity of cash, its susceptibility to accidental and intentional violations causes the need for timely, systematic and continuous internal control of their safety and movement $[16,17]$.

Each economic entity must ensure thorough control of cash on hand and non-cash circulation in bank accounts.

Internal control should be carried out by observing the following principles:

- purposefulness - cash control should be purposeful, the results of control should be provided to specific enterprise management systems [18];

- objectivity - when control measures should apply methods of verification, which allow to form an objective opinion about the state of funds [19];

- consistency - control measures should be carried out regularly and should be systematic [20];

- timeliness - internal control of funds must be implemented in a timely manner, so that the information obtained as a result of its implementation, in time to provide the management system to make management decisions [21];

- scientific validity - in the process of internal control general scientific methods of research should be applied, with the help of which a general idea of cash flow at an enterprise is formed [22];

- comprehensiveness - during internal control of monetary funds all aspects of management of financial and economic activity of an enterprise are subject to verification $[23]$;

- rationality - the costs of implementing internal control of cash flows should be substantially lower than the results of its implementation [24].

The purpose of internal control of cash transactions is to:

- preventing violations of regulations regarding cash accounting;

- ensuring the safety of funds;

- determining the legality and reliability of accounting and reporting data;

- establishing the compliance of cash accounting organization with the provisions adopted in the accounting policy of the enterprise;

- developing and implementing recommendations for enhancing the effective use of cash resources.

- systematic check of cash flows of the enterprise;

- assessment of the real value of monetary resources, determining their purpose.

\section{Materials and Methods}

From the point of view of time factor the internal control procedures are divided into preliminary, current and follow-up.

At preliminary control all actions are directed on prevention and avoidance of illegal and erroneous actions of officials before implementation of economic operations on cash flow. In this case the degree of legality and expediency of these operations is determined. Apart from the internal control service, the preliminary control is carried out by officials in the process of their functional tasks. 
During the current inspection control measures are performed in the course of fulfillment of economic transactions with the purpose of timely identification of deviations from the requirements of regulatory legal acts and prompt reflection of economic transactions in the accounting and reporting.

Current control involves checking the expenditure of cash documents before payment; completeness of crediting, availability and safety of cash in hand and in current accounts in the bank; correct issuance and crediting of cash on account, availability of supporting documents; identity of the data of synthetic and analytical accounting.

In the case of subsequent control, the check is carried out after the business transactions.

In this case:

- the legality, reliability and economic feasibility of transactions that are made in the process of financial and economic enterprise;

- the financial state, solvency, liquidity and financial stability of the enterprise are checked;

- thematic verification of separate types of transactions characterizing the cash flows of the enterprise is conducted.

Results of measures during preliminary, current and subsequent internal control are the basis for development of recommendations on prevention and elimination of revealed violations and deviations.

Internal control of cash includes the following areas: cash flow check; cash flow check on current, currency and special accounts in banks; check of correctness of documented cash flow transactions; comprehensive analytical evaluation of transactions on bank accounts. All lines of verification are performed on a continuous basis in the context of cash flows. In the case of the continuous method, part of the documents for the entire reporting period may be inspected, or the entire set of documents may be inspected over several months.

Main methods of internal control of cash:

1. Inventory. Inventory is a method of controlling the actual availability and safety of funds of the enterprise, reconciliation of actual data with the indicators of accounting on a certain date. This method makes it possible to identify errors, shortages, abuses, and to identify the guilty parties;

2. Mutual control - a method involving comparison of the amount of one and the same economic operation in the accounting of cash flow, contained in different documents and accounting registers;

3. Inspection - a method constituting an inspection of primary documents on the movement of funds according to their form and the essence of the reflected facts of economic life;

4. Observation - a method in which internal controllers monitor the performance of control procedures by employees of economic services, for example, such procedures as the recounting of cash in hand;

5. Confirmation is a method that allows obtaining information about the objectivity of recording in the accounting of the conducted business operations and the reality of balances in the cash accounting accounts;

6. Arithmetic check - a method of control, which allows to determine the correctness of calculations made in the documents, revealing theft and shortage of funds;

7. Formal check - a method of control, which allows detecting defects in the execution of documents on cash accounting, the correctness of filling in the details and the presence of unspecified corrections;

8. Tracing is a method of control, with the help of which correctness of reflection of data in primary accounting, registers, General Ledger, correspondent accounts is checked;

9. Analytical procedures - a method of control through which financial and economic 
indicators characterizing cash flows of the enterprise are assessed; atypical or incorrectly reflected in the accounting business operations and causes of such errors are revealed;

10. Logical check - a method of control, with the help of which the possibility and expediency of cash flow expenditures are evaluated, as well as the relationship between operations related to cash flow is established;

11. Cross-checking - a method of control, in which different copies of the same document on cash flow, located in different divisions of the enterprise or in different economic entities, are compared.

The considered methods, being integrated into a unified system, are applied at internal control of cash and promote increase of efficiency of control measures.

\section{Results}

Planning is one of the key stages of internal control and allows the development of an overall strategy and detailed approach to conducting effective control procedures. When planning, an internal control program is developed (Table 1) In developing the program, consideration should be given to the resources for internal control, viz:

- the staff that will carry out the audit;

- normative and information support of the audit;

- methodological support of the audit.

Internal Control Working Document (ICWD) «Internal Control Program of Cash Transactions». allows to systematize control measures, to determine the nature of the audit and control procedures applied and, as a result, to increase the quality of working documentation formed by the results of the audit.

At the initial stage of cash flow transactions checking it is necessary to get full and trustworthy information about the organization of accounting and internal control systems at the enterprise. Using such control methods as testing, observation, inventory control, an internal controller can establish compliance with cash discipline, the degree of organization of control over cash transactions, including currency transactions, the order of payments from the settlement accounts of the enterprise.

We suggest using working document of internal control for testing (table 2). 
Table 1. Internal Control Working Document (ICWD) «Internal Control Program of Cash Transactions».

\begin{tabular}{|c|c|c|c|c|c|c|}
\hline 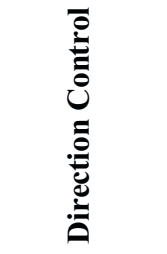 & 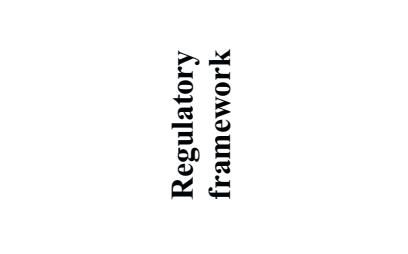 & 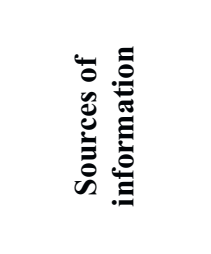 & 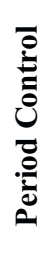 & 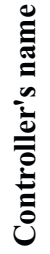 & 竞: & 总 \\
\hline 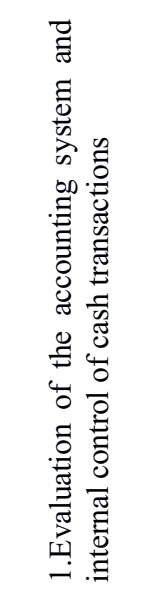 & $\begin{array}{l}\text { Federal Law «On accounting»; } \\
\text { Instructions of the Central } \\
\text { Bank of the Russian } \\
\text { Federation dated } 11.03 .14 \text { № } \\
3210-\mathrm{U} \text { «On the procedure for } \\
\text { conducting cash transactions } \\
\text { by legal entities and a } \\
\text { simplified procedure for } \\
\text { conducting cash transactions } \\
\text { by individual entrepreneurs } \\
\text { and small businesses» and } \\
\text { Instructions the Central Bank } \\
\text { of the Russian Federation } \\
\text { dated 07.10.13 № 3073-U «On } \\
\text { the implementation of cash } \\
\text { payments» }\end{array}$ & 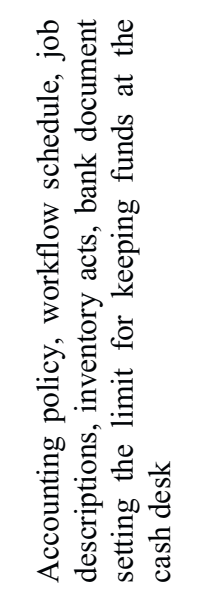 & 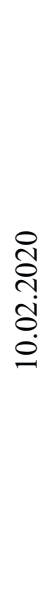 & 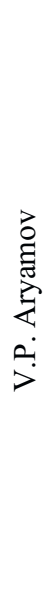 & $\begin{array}{l}\bar{D} \\
\overline{0} \\
\text { in }\end{array}$ & 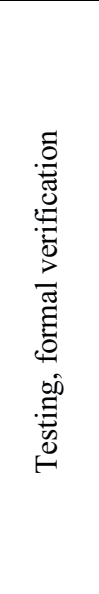 \\
\hline $\begin{array}{l}2 . \\
\text { Checking } \\
\text { cash } \\
\text { transactions }\end{array}$ & $\begin{array}{l}\text { Instructions of the Central } \\
\text { Bank of the Russian } \\
\text { Federation dated 11.03.14 № } \\
3210-\mathrm{U} \text { «On the procedure for } \\
\text { conducting cash transactions } \\
\text { by legal entities and a } \\
\text { simplified procedure for } \\
\text { conducting cash transactions } \\
\text { by individual entrepreneurs } \\
\text { and small businesses» and } \\
\text { Instructions the Central Bank } \\
\text { of the Russian Federation } \\
\text { dated 07.10.13 № 3073-U «On } \\
\text { the implementation of cash } \\
\text { payments». }\end{array}$ & $\begin{array}{l}\text { Cash book, } \\
\text { inventory acts, } \\
\text { incoming and } \\
\text { outgoing cash } \\
\text { documents, } \\
\text { bank document } \\
\text { setting the limit } \\
\text { for keeping } \\
\text { funds at the } \\
\text { cash desk, } \\
\text { cashier reports, } \\
\text { documents } \\
\text { confirming the } \\
\text { legal justification for } \\
\text { justing cash } \\
\text { issuing from the cash } \\
\text { desk }\end{array}$ & 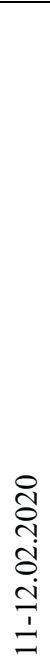 & 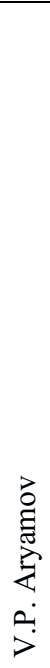 & $\begin{array}{l}\text { :금 } \\
\text { in }\end{array}$ & 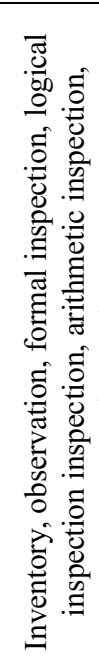 \\
\hline
\end{tabular}




\begin{tabular}{|c|c|c|c|c|c|c|}
\hline $\begin{array}{l}3 . \\
\text { Checking } \\
\text { funds in } \\
\text { bank } \\
\text { accounts }\end{array}$ & $\begin{array}{l}\text { Civil Code of the Russian } \\
\text { Federation; Federal Law of } \\
27.06 .2011 \text { №. 161-FL «On } \\
\text { the National Payment } \\
\text { System»; Federal Law «On } \\
\text { Currency Regulation and } \\
\text { Currency Control» dated } \\
10.12 .2003 \text { No. 173-FL, } \\
\text { «Regulations on the Rules for } \\
\text { Transferring Funds» } \\
\text { (approved Bank of Russia } \\
\text { June 19, 2012 № 383-P), } \\
\text { Letter of the Central Bank of } \\
\text { the Russian Federation dated } \\
\text { August 24, 2004 № 36-3/1643 } \\
\text { «On settlements under a letter } \\
\text { of credit» }\end{array}$ & $\begin{array}{l}\text { Bank account } \\
\text { agreements, } \\
\text { bank } \\
\text { statements with } \\
\text { supporting } \\
\text { documents } \\
\text { (payment } \\
\text { orders, } \\
\text { collection } \\
\text { orders), } \\
\text { correspondence } \\
\text { with servicing } \\
\text { banks, } \\
\text { analytical and } \\
\text { synthetic } \\
\text { accounting } \\
\text { registers }\end{array}$ & 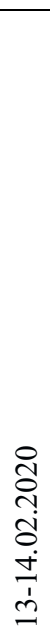 & 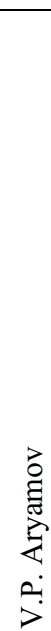 & $\begin{array}{l}. \overline{0} \\
\dot{0}\end{array}$ & 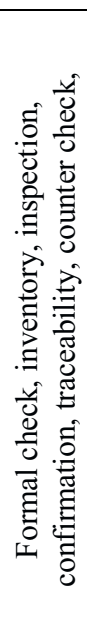 \\
\hline
\end{tabular}

Table 2. Internal Control Working Document (ICWD) «Test of cash transactions accounting and internal control system evaluation».

\begin{tabular}{|c|c|c|c|c|}
\hline \multirow{2}{*}{ Contents of the question } & \multicolumn{3}{|c|}{ Answer content } & \multirow{2}{*}{ Note } \\
\hline & Yes & No & Partial & \\
\hline \multicolumn{5}{|c|}{ Evaluation of the organization of the accounting system of cash } \\
\hline $\begin{array}{l}\text { 1. Are the responsibilities and } \\
\text { authorities for compiling primary } \\
\text { documents and maintaining } \\
\text { synthetic and analytical accounting } \\
\text { of cash transactions differentiated? }\end{array}$ & + & & & $\begin{array}{l}\text { Job descriptions have been } \\
\text { developed that define the duties } \\
\text { and powers of employees of the } \\
\text { accounting service }\end{array}$ \\
\hline $\begin{array}{l}\text { 2. Does the company develop an } \\
\text { accounting policy, including the } \\
\text { part regulating cash accounting? }\end{array}$ & + & & & $\begin{array}{l}\text { An accounting policy has been } \\
\text { developed, which is approved by } \\
\text { the head of the enterprise }\end{array}$ \\
\hline $\begin{array}{l}\text { 3. Has the accounting department } \\
\text { developed a document flow } \\
\text { schedule? }\end{array}$ & + & & & $\begin{array}{l}\text { In the accounting department of } \\
\text { the enterprise there is a } \\
\text { developed workflow schedule } \\
\text { that determines the divisions that } \\
\text { the document and its executors } \\
\text { must go through, the period of its } \\
\text { stay in each of the divisions. }\end{array}$ \\
\hline $\begin{array}{l}\text { 4. Do you comply with deadlines } \\
\text { for documenting cash transactions? }\end{array}$ & + & & & $\begin{array}{l}\text { The deadlines for documenting } \\
\text { cash transactions are respected }\end{array}$ \\
\hline $\begin{array}{l}\text { 5. Are the principles of timeliness, } \\
\text { completeness and legality of cash } \\
\text { flow accounting complied with? }\end{array}$ & + & & & $\begin{array}{l}\text { Cash flow is reflected in the } \\
\text { accounting records in a timely } \\
\text { manner, in full and in accordance } \\
\text { with regulatory enactments. }\end{array}$ \\
\hline $\begin{array}{l}\text { 6. Is cash accounting automated in } \\
\text { the accounting department of the } \\
\text { company? }\end{array}$ & + & & & $\begin{array}{l}\text { The program 1C Accounting } 8.3 \\
\text { is used }\end{array}$ \\
\hline $\begin{array}{l}\text { 7. Are there any deadlines for } \\
\text { documenting cash flows? }\end{array}$ & + & & & $\begin{array}{l}\text { The timing of cash flow is } \\
\text { determined by the document } \\
\text { flow schedule }\end{array}$ \\
\hline $\begin{array}{l}\text { 8. Are the principles of timeliness, } \\
\text { completeness and legality of cash } \\
\text { flow accounting observed? }\end{array}$ & + & & & $\begin{array}{l}\text { Cash flow is recorded in a timely } \\
\text { manner, in full and in accordance } \\
\text { with regulatory enactments. }\end{array}$ \\
\hline $\begin{array}{l}\text { 9. Is the reconciliation of synthetic } \\
\text { and analytical accounting data }\end{array}$ & + & & & $\begin{array}{l}\text { Synthetic and analytical } \\
\text { accounting data are reconciled at }\end{array}$ \\
\hline
\end{tabular}




\begin{tabular}{|l|l|l|l|l|}
\hline systematically carried out? & & & the end of the reporting period \\
\hline \multicolumn{1}{|c|}{ Assessment of the organization of the internal control system for cash transactions } \\
\hline $\begin{array}{l}\text { 1. Is there an agreement on } \\
\text { material responsibility concluded } \\
\text { with the person who performs cash } \\
\text { transactions? }\end{array}$ & + & $\begin{array}{l}\text { The company concludes an } \\
\text { agreement on material } \\
\text { responsibility with the person } \\
\text { who performs cash transactions }\end{array}$ \\
\hline $\begin{array}{l}\text { 2. Are all the requisites filled out } \\
\text { in the documents for cash } \\
\text { accounting? }\end{array}$ & + & & $\begin{array}{l}\text { All the requisites are filled out in } \\
\text { the documents for cash } \\
\text { accounting }\end{array}$ \\
\hline $\begin{array}{l}\text { 3. Are all necessary signatures on } \\
\text { the documents recording cash } \\
\text { flow? }\end{array}$ & + & $\begin{array}{l}\text { The documents recording cash } \\
\text { flows have all the necessary } \\
\text { signatures }\end{array}$ \\
\hline $\begin{array}{l}\text { 4. Regularity of reconciliation of } \\
\text { data contained in accounting } \\
\text { registers with the data of primary } \\
\text { documents }\end{array}$ & + & $\begin{array}{l}\text { Data of accounting registers are } \\
\text { regularly checked against the } \\
\text { data of primary documents }\end{array}$ \\
\hline $\begin{array}{l}\text { 5. Is the safety of funds at the } \\
\text { enterprise ensured? }\end{array}$ & + & $\begin{array}{l}\text { The cash room is equipped with } \\
\text { an alarm system. Cash is kept in } \\
\text { a fireproof safe }\end{array}$ \\
\hline $\begin{array}{l}\text { 5. Are the balances of bank } \\
\text { accounts reconciled on a monthly } \\
\text { basis? }\end{array}$ & + & $\begin{array}{l}\text { Chief accountan reconciles } \\
\text { balances of bank accounts on a } \\
\text { monthly basis }\end{array}$ \\
\hline $\begin{array}{l}\text { 6. Is the accuracy and timeliness of } \\
\text { reflection of data contained in bank } \\
\text { statements in accounting registers } \\
\text { checked? }\end{array}$ & + & $\begin{array}{l}\text { The chief accountant checks the } \\
\text { accuracy and timeliness of the } \\
\text { data contained in the bank } \\
\text { statements in the accounting } \\
\text { registers on a monthly basis }\end{array}$ \\
\hline $\begin{array}{l}\text { 7. Are surprise cash inventories } \\
\text { performed? }\end{array}$ & + & $\begin{array}{l}\text { Unannounced stock-taking of } \\
\text { cash at the enterprise is } \\
\text { conducted check the intended }\end{array}$ \\
\hline $\begin{array}{l}\text { 8. Is the purposeful use of funds } \\
\text { coming from bank accounts } \\
\text { checked? }\end{array}$ & + & $\begin{array}{l}\text { Regularly checks } \\
\text { use of cash coming from the } \\
\text { bank accounts }\end{array}$ \\
\hline $\begin{array}{l}\text { 9. Is the timeliness of the return of } \\
\text { accountable amounts checked? }\end{array}$ & + & $\begin{array}{l}\text { The chief accountant regularly } \\
\text { checks the timeliness of } \\
\text { repayment of the amounts on } \\
\text { hand }\end{array}$ \\
\hline
\end{tabular}

Using these working documents, the internal controller tests the accounting and internal control systems, assesses the degree of safety of the intended use of funds belonging to the economic entity. In this case areas of accounting activity are revealed, to which it is necessary to pay close attention in the process of internal control.

Internal control of cash operations is carried out in the following sequence:

1. Inventory of the cash register is carried out:

- the cashier provides documents that record the operations of the day preceding the check; available cash and other valuables (securities and monetary documents);

- the results obtained during an inventory of cash and cash documents shall be compared with the accounting data. In the case of identifying surpluses or shortages, the internal controller recommends establishing the reasons for their formation, since surpluses may be formed during the receipt and issuance of cash as a result of intentional and unintentional errors;

2. The availability of an agreement on material responsibility with the cashier, compliance of the cashier's workplace with the established requirements, ensuring the safety of cash in hand;

3. Verification of correctness of documentary registration of operations on cash flow 
accounting:

- whether cash documents are executed in time. If primary documents are not executed in time, the document flow schedule is violated, accounting errors occur;

- whether documents are executed qualitatively, whether all signatures are available in documents confirming the fact of cash disbursement;

4. The completeness and timeliness of receipt of cash from the bank is checked by mutual reconciliation of identical amounts in bank statements and cash receipt vouchers. Herewith, formal verification of documents is applied. Besides, cash receipts transactions are checked on their merits from the point of view of their legality. This control procedure makes it possible to identify cases of receipt of significant amounts of cash by the cash desk, which by drawing up fictitious documents are appropriated by officials. In addition, it is necessary to check the completeness of the entry of revenue from the sale of products in cash. In this case, the records of cash documents, on the basis of which cash is accepted, with the documents reflecting the sale of products are reconciled;

5. Verification of cash outflow involves formal verification of the correctness of primary documents accounting for cash outflow; normative verification of the validity of cash outflow, depending on the direction of the outflow;

6. Checking the timeliness and accuracy of reflection of cash transactions in the accounts, as it affects the reliability of financial statements, unreasonable veiling of income and reducing the taxable base.

To fix the revealed violations by the results of cash operations audit we propose to use the following working document (Table 3).

Table 3. Internal Control Working Document (ICWD) «Report on the results of cash operations audit».

\begin{tabular}{|c|c|c|c|c|c|c|c|c|}
\hline \multirow{3}{*}{ 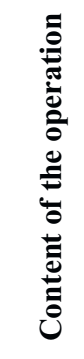 } & \multirow{3}{*}{ 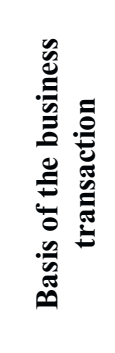 } & \multicolumn{2}{|c|}{$\begin{array}{c}\text { Amount, } \\
\text { rub. }\end{array}$} & \multicolumn{4}{|c|}{ Correspondence of accounts } & \multirow{3}{*}{$\begin{array}{l}\text { Identified } \\
\text { violations }\end{array}$} \\
\hline & & \multirow{2}{*}{ 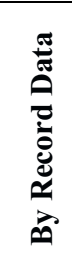 } & \multirow{2}{*}{ 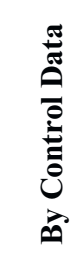 } & \multicolumn{2}{|c|}{$\begin{array}{c}\text { By accounting } \\
\text { data }\end{array}$} & \multicolumn{2}{|c|}{ By control data } & \\
\hline & & & & 竞 & 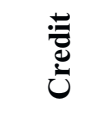 & 䒕 & & \\
\hline 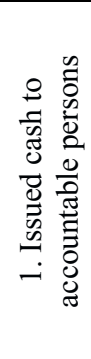 & 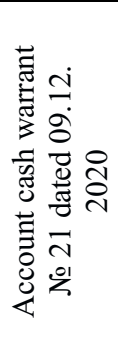 & $\begin{array}{l}\infty \\
i n\end{array}$ & $\underset{\infty}{\infty}$ & 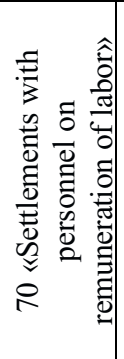 & 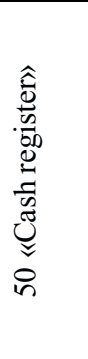 & 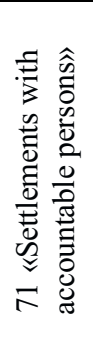 & 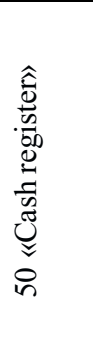 & $\begin{array}{l}\text { For the } \\
\text { issuance of } \\
\text { funds for the } \\
\text { report, account } \\
70 \text { «Payments } \\
\text { with personnel } \\
\text { for labor } \\
\text { remuneration» } \\
\text { is unreasonably } \\
\text { used }\end{array}$ \\
\hline
\end{tabular}




\begin{tabular}{|c|c|c|c|c|c|c|c|c|}
\hline 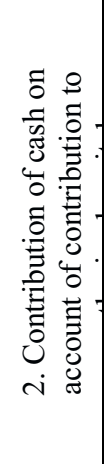 & 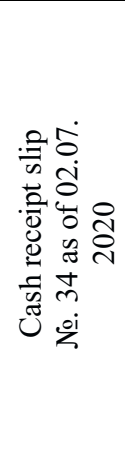 & \&্ర & $\underset{f}{\stackrel{8}{8}}$ & 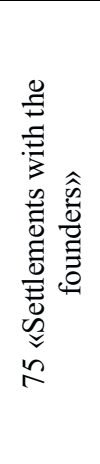 & 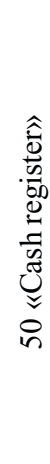 & 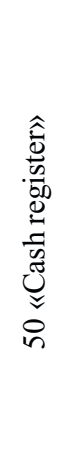 & 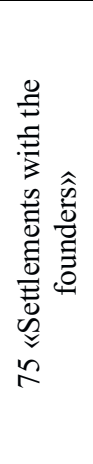 & $\begin{array}{l}\text { Incorrect } \\
\text { correspondence } \\
\text { of invoices. } \\
\text { The primary } \\
\text { document } \\
\text { incorrectly } \\
\text { reflects the } \\
\text { amount of cash } \\
\text { in the account } \\
\text { of a } \\
\text { contribution to } \\
\text { the authorized } \\
\text { capital }\end{array}$ \\
\hline
\end{tabular}

Verification of bank account transactions involves the following procedures:

- establishing the availability of accounts (settlement, currency and special accounts) that the enterprise has with the banks;

- the legality and accuracy of documentation of operations made on bank accounts is checked;

- verification of the timeliness and completeness of the receipt of cash that came to the bank accounts;

- verification of the completeness and in accordance with the submitted invoices paid funds from the settlement accounts of the enterprise;

- whether the taxes to the budget and insurance premiums to non-budgetary funds are paid in time;

- the financial status of the enterprise is analyzed, solvency is evaluated, and causes of arrears in settlements with contractors are determined;

- timeliness of receipt, entry and intended use of funds from the current account to the cash desk is checked;

- the economic expediency and reliability of transactions on current bank accounts are monitored;

- checks whether the data on the movement and availability of cash, which are reflected in the documents;

- correctness of correspondence of accounts on operations on settlement accounts in banks is checked;

- drawing up the results of internal control over banking operations.

When checking bank transactions, each account should be checked separately. In this connection we consider it necessary to use working document «Verification of bank accounts availability» (Table 4)

Table 4. Internal control working document (ICWD) «Verification of Existence of Bank Accounts».

\begin{tabular}{|l|c|l|l|c|}
\hline $\begin{array}{c}\text { Type of } \\
\text { account }\end{array}$ & Account number & $\begin{array}{l}\text { The bank } \\
\text { where the } \\
\text { account is } \\
\text { opened }\end{array}$ & $\begin{array}{c}\text { Basis for opening an } \\
\text { account }\end{array}$ & $\begin{array}{c}\text { Identified } \\
\text { deviations }\end{array}$ \\
\hline $\begin{array}{l}\text { Current } \\
\text { account }\end{array}$ & 40702810012120000000 & $\begin{array}{l}\text { Public Joint } \\
\text { Stock } \\
\text { Company } \\
\text { (PJSC) } \\
\text { Sberbank }\end{array}$ & $\begin{array}{l}\text { Banking service } \\
\text { agreement No. 362 } \\
\text { dated 02.07.2019 }\end{array}$ & - \\
\hline
\end{tabular}




\begin{tabular}{|l|l|l|l|l|}
\hline $\begin{array}{l}\text { Foreign } \\
\text { currency } \\
\text { account }\end{array}$ & 40702800086110000000 & $\begin{array}{l}\text { Public Joint } \\
\text { Stock }\end{array}$ & $\begin{array}{l}\text { Company } \\
\text { Banking Service }\end{array}$ & \\
& & (PJSC) & agreement No. 291 & - \\
& & «Akbarc» & dated 12.08.2019 & \\
& Bank & & \\
\hline
\end{tabular}

This document allows you to systematize information about the current accounts of the economic entity, opened in different banks, and to record the identified deviations in the procedure of their opening.

When checking the current account transactions, it is necessary to reconcile the bank statements, accounting and reporting registers. If discrepancies are identified, the reasons should be identified.

Reconciliation of bank statements and the documents attached to them reveal facts when funds are written off without documentation, or are written off for purposes not described in the documents.

The examination of bank documents reveals:

- illegal banking operations carried out without contracts. thus an illegal banking operation is an operation in the course of which the debts of an enterprise with which the audited organization has no contractual relationship is repaid. also, it is an illegal banking operation to pay the bills of other companies on cashless transactions;

- whether material assets are received and paid in full and in a timely manner;

- whether the submitted documents for credits and loans to legal entities and individuals are reliable;

- whether the financial condition and sources of financing allow the granting of loans.

In order to improve the checking of current account transactions we suggest using the working document «Questionnaire for Control over Safekeeping and State of Accounting of Bank Transactions and Purposeful Use of Non-Cash Funds» (Table 5)

Table 5. ICWD «Questionnaire for Control over Safekeeping and State of Accounting of Bank Transactions and Purposeful Use of Non-Cash Funds».

\begin{tabular}{|l|l|l|l|l|}
\hline \multicolumn{2}{|c|}{ Contents of the question } & \multicolumn{2}{|c|}{ Contents Of Answer } & \multicolumn{2}{|c|}{ Note } \\
\hline & Yes & No & Partial & \\
\hline $\begin{array}{l}\text { 1. Is it legal to make } \\
\text { settlements by non-cash } \\
\text { method? }\end{array}$ & + & & & $\begin{array}{l}\text { Settlements made by non-cash } \\
\text { method are legal. The legality of the } \\
\text { transactions is controlled by the chief } \\
\text { accountant. }\end{array}$ \\
\hline $\begin{array}{l}\text { 2. Are the rules of banking } \\
\text { operations followed? }\end{array}$ & + & & & $\begin{array}{l}\text { Compliance with the rules for } \\
\text { conducting banking operations is } \\
\text { monitored by the chief accountant. }\end{array}$ \\
\hline $\begin{array}{l}\text { 3. Are the banking } \\
\text { operations performed } \\
\text { authentic and reliable? }\end{array}$ & + & & & $\begin{array}{l}\text { The banking transactions performed } \\
\text { are authentic and reliable. This fact is } \\
\text { confirmed by an inventory of non- } \\
\text { cash settlement transactions. }\end{array}$ \\
\hline $\begin{array}{l}\text { 4. Is each banking } \\
\text { transaction reflected in } \\
\text { synthetic and analytical } \\
\text { ledgers? }\end{array}$ & + & & $\begin{array}{l}\text { Each banking operation is reflected in } \\
\text { synthetic and analytical accounting } \\
\text { registers. }\end{array}$ \\
\hline $\begin{array}{l}\text { 5. Are funds fully capitalized } \\
\text { on current accounts with } \\
\text { banks? }\end{array}$ & + & & $\begin{array}{l}\text { Funds on settlement accounts with } \\
\text { banks are credited in full. Regular } \\
\text { control of the completeness of the } \\
\text { posting is carried out by the chief } \\
\text { accountant. }\end{array}$ \\
\hline 6. Is a permanent inventory & + & & & The company creates a permanent \\
\hline
\end{tabular}




\begin{tabular}{|c|c|c|}
\hline $\begin{array}{l}\text { commission set up to take } \\
\text { inventory of settlement } \\
\text { accounts? }\end{array}$ & & $\begin{array}{l}\text { inventory commission for the } \\
\text { inventory of settlement accounts. }\end{array}$ \\
\hline $\begin{array}{l}\text { 7. Is there an inventory of all } \\
\text { non-cash payments? }\end{array}$ & + & $\begin{array}{l}\text { The company carries out an inventory } \\
\text { of all non-cash payments. }\end{array}$ \\
\hline $\begin{array}{l}8 . \text { Does the actual } \\
\text { availability of funds in the } \\
\text { bank accounts correspond to } \\
\text { the accounting data? }\end{array}$ & + & $\begin{array}{l}\text { The actual availability of funds in } \\
\text { bank accounts corresponds to the } \\
\text { credentials }\end{array}$ \\
\hline $\begin{array}{l}\text { 9. Are non-cash transactions } \\
\text { correctly reflected in the } \\
\text { accounting? }\end{array}$ & + & $\begin{array}{l}\text { Non-cash transactions are recorded } \\
\text { correctly based on bank statements. }\end{array}$ \\
\hline $\begin{array}{l}\text { 10. Do the actual target } \\
\text { expenditures of non-cash } \\
\text { funds correspond to the } \\
\text { planned ones? }\end{array}$ & + & $\begin{array}{l}\text { The actual target expenditures of non- } \\
\text { cash funds correspond to the planned } \\
\text { ones. Regular control is carried out by } \\
\text { the chief accountant. }\end{array}$ \\
\hline $\begin{array}{l}\text { 11. Is the limit of the target } \\
\text { expenditure of non-cash } \\
\text { funds observed? }\end{array}$ & + & $\begin{array}{l}\text { The limit for the target expenditure of } \\
\text { non-cash funds is respected. Regular } \\
\text { control is carried out by the chief } \\
\text { accountant. }\end{array}$ \\
\hline $\begin{array}{l}\text { 12. Are there any } \\
\text { applications for the use of } \\
\text { non-cash funds? }\end{array}$ & + & $\begin{array}{l}\text { The enterprise has applications for the } \\
\text { expenditure of non-cash funds. }\end{array}$ \\
\hline
\end{tabular}

Using this working document, the internal controller can objectively assess the safety and state of accounting of bank transactions, the intended use of non-cash funds.

Checking the cash that came to the current accounts, it is necessary to establish the completeness of their enrollment and correctness of accounting. To do this, the proceeds, which comes from customers to the account is reconciled with the data on sales and settlement accounts with buyers and customers. In addition, applying the method of crosschecking, you can control the flow of funds from other debtors. In this case, bank statements, attached documents and accounting records in the audited entity and in the organization-counterparty on relevant transactions, according to the requests made by the controller.

Operations on transferring money to repay debts to suppliers, contractors and other creditors should be thoroughly analyzed. In this case it is also advisable to apply reconciliation of interrelated primary documents on homogeneous operations.

To formalize the results of checking cash flow operations on current bank accounts we propose to use working document of internal control (Table 6).

Table 6. Internal Control Working Document (ICWD) «Verification of cash flow operations on current accounts at the bank».

\begin{tabular}{|c|c|c|c|c|c|c|}
\hline \multirow[b]{2}{*}{$\begin{array}{c}\text { Business } \\
\text { transaction }\end{array}$} & \multirow[b]{2}{*}{$\begin{array}{c}\text { Counterpa } \\
\text { rty name }\end{array}$} & \multirow{2}{*}{$\begin{array}{c}\text { Document, } \\
\text { number } \\
\text { and date }\end{array}$} & \multicolumn{2}{|c|}{ Amount, rub. } & \multirow[b]{2}{*}{$\begin{array}{c}\text { Deviatio } \\
\text { ns, rub. }\end{array}$} & \multirow[b]{2}{*}{$\begin{array}{c}\text { Reasons for } \\
\text { deviations }\end{array}$} \\
\hline & & & $\begin{array}{l}\text { According } \\
\text { to the } \\
\text { enterprise }\end{array}$ & $\begin{array}{l}\text { According to } \\
\text { the } \\
\text { counterparty }\end{array}$ & & \\
\hline $\begin{array}{l}1 . \quad \text { Payment } \\
\text { was made from } \\
\text { the current } \\
\text { account for the } \\
\text { purchased } \\
\text { wheat flour of } \\
\text { the highest } \\
\text { grade }\end{array}$ & $\begin{array}{l}\text { LLC } \\
\text { «Agro- } \\
\text { Trade» }\end{array}$ & $\begin{array}{l}\text { Invoice No. } \\
812 \text { dated } \\
\text { August 17, } \\
2020\end{array}$ & 20600 & 19700 & +900 & $\begin{array}{l}\text { According to } \\
\text { the } \\
\text { contractor's } \\
\text { data, payment } \\
\text { was made for } \\
\text { baking wheat } \\
\text { flour of the } \\
\text { 1st grade. }\end{array}$ \\
\hline
\end{tabular}


ICWD «Verification of cash flow operations on current accounts at the bank» allows to systematize the results of verification of cash flow operations on bank accounts, their appropriateness and validity. This document reflects the revealed deviations associated with abuse, theft and shortage of material assets. In particular, economic entities transfer funds for purchased inventory items that either did not arrive at the enterprise or the documents indicate a different assortment than what was actually received.

In the process of control, the controller establishes validity and correctness of transfer of current and deposited amounts of labor remuneration, deductions under writs of execution, liabilities by verifying transferred amounts with primary accounting documents and by establishing reality of recipients of transfers that are specified in the list of transfer addresses.

At the next stage of internal control of banking operations operations on special accounts in the bank for settlements by letter of credit, checks, deposit accounts, etc. are checked. Similar to other bank accounts, checking is performed in the following sequence:

- receive information about special accounts, about the availability of contracts for their service;

- the identity of the amounts reflected in the bank statements, accounting and reporting is checked;

- the compliance of primary documents and bank statements is checked

- the completeness of bank statements is checked;

- the legality, validity and expediency of operations on special accounts in the bank is checked;

- the correctness of reflection in the accounting of transactions on special accounts in the bank is checked;

- the correctness, legality, observance of the terms of validity of letters of credit is checked;

- it is checked whether the documents for transactions that are paid for by checks are correctly drawn up, for transactions related to the movement of targeted funding.

To fix the identified violations based on the results of checking transactions on settlement accounts, we suggest using the following working document (Table 7).

This document summarizes information on the revealed irregularities in certain areas of the audit and recommendations for their elimination, the regulatory framework, sources of information and control procedures used in the course of the audit. Internal Control Working Document (ICWD) «Identified Violations in Accounting of Bank Operations» will allow an internal controller to make an objective report about the results of inspection and form an information base for taking management decisions 
Table 7. Internal Control Working Document (ICWD) «Identified Violations in Accounting for Bank Transactions».

\begin{tabular}{|l|l|l|l|l|l|l|}
\hline & & &
\end{tabular}




\begin{tabular}{|c|c|c|c|c|c|c|}
\hline $\begin{array}{l}3 . \\
\text { Verification } \\
\text { of } \\
\text { transactions } \\
\text { on special } \\
\text { accounts in } \\
\text { banks }\end{array}$ & $\begin{array}{l}\text { Opening a } \\
\text { letter of } \\
\text { credit on } \\
\text { terms that } \\
\text { differ from } \\
\text { those } \\
\text { stipulated } \\
\text { by the } \\
\text { contract }\end{array}$ & $\begin{array}{l}\text { Civil Code } \\
\text { of the } \\
\text { Russian } \\
\text { Federation. } \\
\text { Letter of the } \\
\text { Central } \\
\text { Bank of the } \\
\text { Russian } \\
\text { Federation } \\
\text { dated } \\
\text { August } 24 . \\
2004 \text { № } 36- \\
3 / 1643 \text { «On } \\
\text { settlements } \\
\text { under a letter } \\
\text { of credit». } \\
\text { «Regulations } \\
\text { on the rules } \\
\text { for } \\
\text { transferring } \\
\text { funds» } \\
\text { (approved } \\
\text { by the Bank } \\
\text { of Russia on } \\
\text { June } 19 . \\
2012 \quad \text { № } \\
383-P \text { ) }\end{array}$ & $\begin{array}{l}\text { Applications } \\
\text { for opening } \\
\text { a letter of } \\
\text { credit. letter } \\
\text { of credit }\end{array}$ & 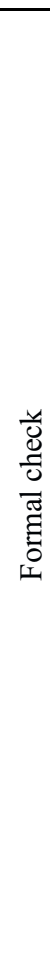 & $\begin{array}{l}\hat{b} \\
\infty \\
\stackrel{\infty}{0}\end{array}$ & $\begin{array}{l}\text { Recommendations } \\
\text { to bring the terms } \\
\text { of opening a letter } \\
\text { of credit in } \\
\text { accordance with } \\
\text { the contract }\end{array}$ \\
\hline
\end{tabular}

\section{Discussion}

Based on the results of internal control, the company's management makes a decision to improve the efficiency of the use of cash based on the creation of a liquidity management system. The creation of the enterprise liquidity management system includes the following stages:

- implementation of operational cash flow management through the formation of a payment calendar;

- effective use of free cash flows;

- effective management and control of receivables and payables;

- creation of an efficient system for the purchase and storage of inventory;

- creating a system that allows tracking the actual status and availability of material resources, compliance with the schedule of deliveries and payments.

In order to increase the efficiency of the use of monetary resources, in addition to the direct management of cash, it is necessary to manage the sources of the formation of these funds [25]. Before making a decision to increase the efficiency of the use of cash resources, it is necessary to analyze their composition, dynamics, structure to identify problematic issues related to their management $[26,27]$. For the analysis it is recommended to use the data of the financial and management reporting for the last five years.

The purpose of the cash flow analysis is to identify the causes of cash shortages or surpluses, determine the sources and uses of cash flows. In addition, in the process of analysis, the financial sustainability and profitability of the enterprise are evaluated.

By analyzing the cash flow, it is possible to characterize the degree of self-financing, financial potential and financial well-being of the enterprise, which largely depend on the receipt of cash that ensures the repayment of its liabilities [28]. Lack of cash leads to 
financial difficulties that hinder the implementation of production and financial activities. Excessive cash is also a negative factor, since inflationary processes, depreciation of money, missed opportunities for financial investment and the subsequent extraction of income can cause economic losses. In this connection questions of the analysis of cash flows of the enterprise become especially urgent.

During the analysis cash flow research is carried out by kinds of activity: basic, investment and financial activity.

The main activity is the activity of an economic entity, which brings him the main income. The main activity is the main source of profit and cash.

Investment activities are closely related to the purchase and sale of property related to long-term assets. As a rule, the investment activity of the enterprise is associated with a cash outflow for a certain period of time [29].

Financial activity - the activity on financial support of the functioning of the enterprise, in the course of which changes the amount and composition of equity and borrowed funds. In the course of financial activity, the enterprise receives money from shareholders by issuing securities, pays dividends to shareholders, and takes loans from banks.

Analyzing cash flows, the following conclusions can be made:

- on the amount and sources of cash inflows, directions of their use;

- on the sufficiency of the enterprise's own funds for carrying out investment activities;

- on the enterprise's ability to repay its current liabilities;

- on the sufficiency of profits received for current activity.

Thus, cash flow analysis is of great importance for operational and strategic financial planning of the enterprise.

The source of cash flow analysis is the cash flow statement, in which cash flows are reflected in the context of current, investment and financial activities over the reporting period.

Let us analyse the resulting net cash flow on the basis of the data contained in the Cash Flow Statement (Table 8, Fig. 1)

Table 8. Analysis of productive net cash flow for 2016-2020, thousand rubles.

\begin{tabular}{|c|c|c|c|c|c|c|}
\hline \multirow{2}{*}{$\begin{array}{l}\text { Net cash flow } \\
\text { indicator }\end{array}$} & \multicolumn{5}{|c|}{ Years } & \multirow{2}{*}{$\begin{array}{l}\text { Deviation }(+,-) \\
2020 \text { from } 2016\end{array}$} \\
\hline & 2016 & 2017 & 2018 & 2019 & 2020 & \\
\hline $\begin{array}{l}\text { 1. From current } \\
\text { activities }(\mathrm{NCF})\end{array}$ & 31423 & 22124 & 16975 & 4173 & 5879 & -25544 \\
\hline $\begin{array}{l}2 . \\
\text { investment } \\
\text { activities (NCFi) }\end{array}$ & -835 & -739 & -502 & -283 & -326 & 509 \\
\hline $\begin{array}{l}\text { 3. From financial } \\
\text { activities (NCFf) }\end{array}$ & -27536 & -25969 & -16203 & -3720 & -6779 & 20757 \\
\hline $\begin{array}{l}4 . \quad \text { Effective } \\
\text { (RNCF = NCFc } \\
+ \text { NCFi + NCFf) }\end{array}$ & 3052 & -4584 & 270 & 170 & -1226 & -4278 \\
\hline
\end{tabular}




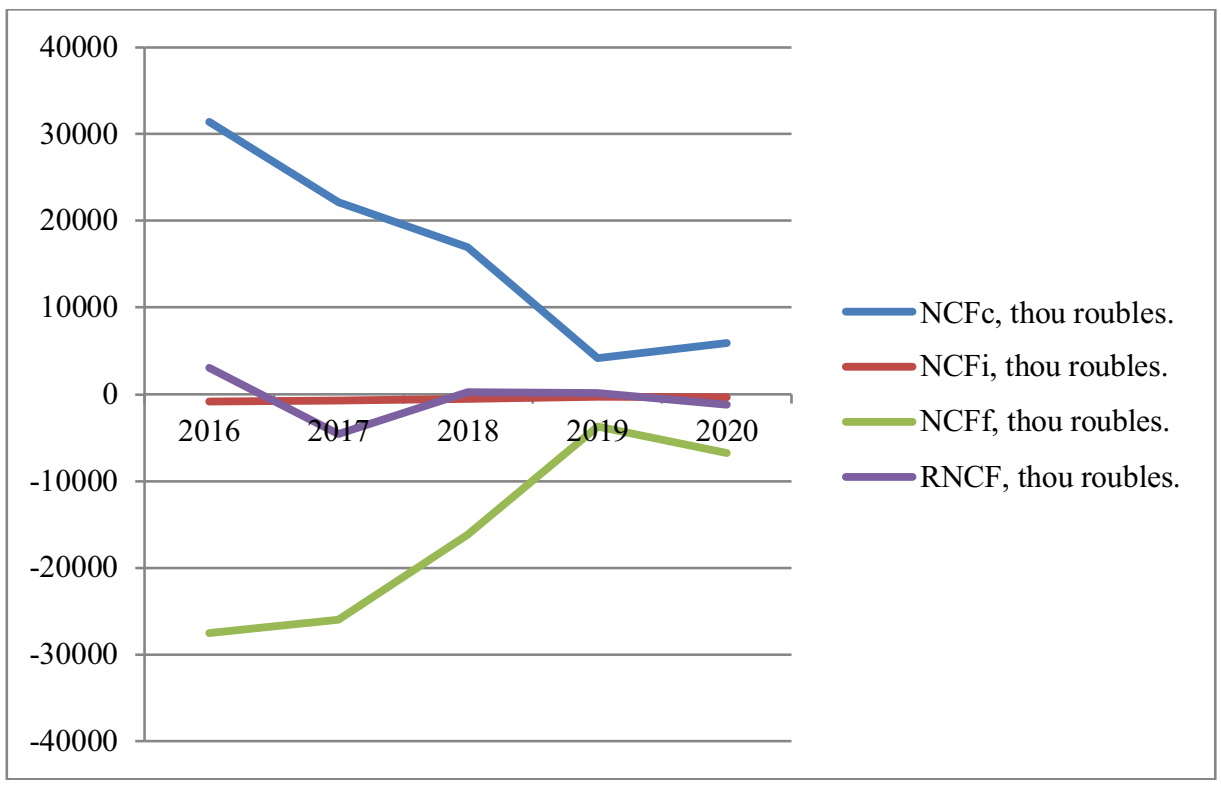

Fig. 1. Dynamics of net cash flow for $2014-2018$.

Based on the data in Table 8 and Figure 1, we can conclude that net cash flow from current activities tends to decrease. This indicator by the end of the analyzed period significantly decreased by 25544 thousand rubles and amounted to 5879 thousand rubles.

Analyzing the indicators of net cash flow from financing and investment activities, we can conclude that the cash flow is negative throughout the examined period, but it still has a tendency to increase.

Based on the data in Table 10 and Figure 1, we can conclude that the resultant net cash flow tends to decrease. The given indicator by the end of the analyzed period decreased by 4278 thousand rubles and made -1226 thousand rubles.

More detailed analysis of net cash flow follows from studying cash flow from current operations (Table 9).

Table 9. Cash flows from current operations in 2016 - 2020, thousand rubles.

\begin{tabular}{|l|c|c|c|c|c|c|}
\hline \multirow{2}{*}{ Indicator name } & \multicolumn{5}{|c|}{ Years } & \begin{tabular}{c} 
Deviation (+, -) \\
\cline { 2 - 7 } in relation to 2019
\end{tabular} \\
\hline $\begin{array}{l}\text { Cash flows from } \\
\text { current operations }\end{array}$ & & & & & & \\
\hline Income - total & 517726 & 270276 & 236487 & 180190 & 195457 & 15267 \\
\hline including: & & & & & & 18396 \\
\hline $\begin{array}{l}\text { from the sale of } \\
\text { products, goods, } \\
\text { works and services }\end{array}$ & 376109 & 264908 & 197807 & 173173 & 191569 & \\
\hline $\begin{array}{l}\text { lease payments, } \\
\text { royalties, fees, } \\
\text { commission } \\
\text { payments }\end{array}$ & 130436 & - & 32975 & 3251 & - & -3251 \\
\hline other supply & 11181 & 5368 & 5704 & 3667 & 3788 & 121 \\
\hline of them: & & & & & & 121 \\
\hline budget subsidies & 11181 & 5368 & 5704 & 3667 & 3788 & - \\
\hline $\begin{array}{l}\text { insurance indemnity } \\
\text { received }\end{array}$ & - & - & - & - & - & \\
\hline
\end{tabular}




\begin{tabular}{|l|c|c|c|c|c|c|}
\hline Payments - total & 486303 & 248152 & 219512 & 176016 & 189577 & 13561 \\
\hline including: for raw & & & & & & 6163 \\
\hline $\begin{array}{l}\text { suppliers farts, materials, } \\
\text { materials } \\
\text { work, services }\end{array}$ & 275218 & 189523 & 133767 & 89052 & 95215 & 680 \\
\hline $\begin{array}{l}\text { in connection with } \\
\text { themuneration of } \\
\text { employees }\end{array}$ & 42107 & 32935 & 30836 & 31245 & 31925 & 5015 \\
\hline $\begin{array}{l}\text { interest on debt } \\
\text { obligations }\end{array}$ & 166787 & 30172 & 35132 & 35465 & 40480 & - \\
\hline $\begin{array}{l}\text { corporate income } \\
\text { tax }\end{array}$ & - & - & - & - & - & 1703 \\
\hline other payments & 2191 & 28522 & 19777 & 20254 & 21957 & 1706 \\
\hline $\begin{array}{l}\text { Balance of cash } \\
\text { flows from current } \\
\text { operations }\end{array}$ & 31423 & 22124 & 16975 & 4173 & 5879 & \\
\hline
\end{tabular}

Table 9 shows that net cash flow from current operations increased by 1,706 thousand rubles in 2020 compared to 2019 and was 5,879 thousand rubles.

In 2020 we received cash from customers for products 191569 thousand rubles, which is $98 \%$ of all cash receipts. Other cash receipts accounted for $2 \%$. Cash receipts in the form of sales $(98 \%)$ indicate that the company receives the main income from its core business.

Payments for current operations in 2020 were 189577 thousand rubles, which is 13561 thousand rubles more than in 2019. Of these, 95215 thousand rubles were paid to suppliers for raw materials, materials, works and services, which is $50 \%$ of the total amount of all payments. 31925 thou. rubles were spent to pay the employees. (17\% of total payments), the amount of interest on credits and loans was 40480 thousand rubles (21\% of total payments). (21\%), and the share of other payments was 12\% (21957 thousand rubles).

So, based on the results obtained, we can conclude that the cash inflow of the enterprise exceeds the outflow, which means that the company is solvent and is able to pay off its liabilities.

Further it is necessary to make the analysis of the money flows from investment operations (table 10).

Table 10. Cash flows from investment operations in 2016 - 2020, thousand rubles.

\begin{tabular}{|c|c|c|c|c|c|c|}
\hline \multirow{2}{*}{ Indicator name } & \multicolumn{5}{|c|}{ Years } & \multirow{2}{*}{$\begin{array}{c}\text { Deviation }(+,-) \\
2020 \text { in relation to } 2019\end{array}$} \\
\hline & 2016 & 2017 & 2018 & 2019 & 2020 & \\
\hline \multicolumn{7}{|l|}{$\begin{array}{l}\text { Cash flows from } \\
\text { investment operations }\end{array}$} \\
\hline Income - total & 1674 & 1370 & 687 & 352 & 1901 & 1549 \\
\hline \multicolumn{7}{|l|}{ including: } \\
\hline $\begin{array}{l}\text { from the sale of non- } \\
\text { current assets (except for } \\
\text { financial investments) }\end{array}$ & 1023 & 928 & - & - & 1578 & 1578 \\
\hline $\begin{array}{l}\text { from the sale of shares of } \\
\text { other organizations } \\
\text { (participation interests) }\end{array}$ & - & - & - & - & - & - \\
\hline $\begin{array}{l}\text { from the return of loans } \\
\text { provided, from the sale of } \\
\text { debt securities (rights to } \\
\text { claim funds to other } \\
\text { persons) }\end{array}$ & 412 & 301 & 381 & 234 & 178 & -56 \\
\hline $\begin{array}{l}\text { dividends, interest on debt } \\
\text { financial investments and } \\
\text { similar receipts from }\end{array}$ & 239 & 141 & 306 & 118 & 145 & 27 \\
\hline
\end{tabular}




\begin{tabular}{|c|c|c|c|c|c|c|}
\hline \multicolumn{7}{|l|}{$\begin{array}{l}\text { equity participation in } \\
\text { other organizations }\end{array}$} \\
\hline other supply & - & - & - & - & - & - \\
\hline Payments - total & 2509 & 2109 & 1189 & 635 & 2227 & 1592 \\
\hline \multicolumn{7}{|l|}{ including: } \\
\hline $\begin{array}{l}\text { in connection with the } \\
\text { acquisition, creation, } \\
\text { modernization, } \\
\text { reconstruction and } \\
\text { preparation for the use of } \\
\text { non-current assets }\end{array}$ & 1997 & 1487 & 580 & 418 & 1843 & 1425 \\
\hline $\begin{array}{l}\text { in connection with the } \\
\text { acquisition of shares of } \\
\text { other organizations } \\
\text { (participation interests) }\end{array}$ & 387 & 280 & 286 & - & 223 & 223 \\
\hline $\begin{array}{l}\text { in connection with the } \\
\text { acquisition of debt } \\
\text { securities (rights to claim } \\
\text { funds against other } \\
\text { persons), provision of } \\
\text { loans to other persons }\end{array}$ & 125 & 342 & 323 & 217 & 161 & -56 \\
\hline $\begin{array}{l}\text { interest on debt liabilities } \\
\text { included in the cost of an } \\
\text { investment asset }\end{array}$ & - & - & - & - & - & - \\
\hline other payments & - & - & - & - & - & - \\
\hline $\begin{array}{l}\begin{array}{l}\text { Balance of cash flows } \\
\text { from } \\
\text { operations }\end{array} \\
\text { investment }\end{array}$ & -835 & -739 & -502 & -283 & -326 & -43 \\
\hline
\end{tabular}

As can be seen from Table 10, the balance of cash flows from investment operations in 2020 amounted to -326 thous. rubles. The main share of cash receipts from investment operations accounts for the amounts from sale of non-current assets (except for financial investments) and amounts to $83 \%$ (1,578 thous. rubles). Also the analysis shows that the main part of payments on investment operations is connected with acquisition, creation, modernization, reconstruction and preparation for use of non-current assets - $82.8 \%(1,843$ thous. rubles). However, it should be noted that the balance of cash flows from investment operations is negative, as the amount of payments exceeds the amount of receipts.

Let's look at the indicators of cash flows from financial operations in the following Table 11.

Table 11. Cash flows from financial operations for 2016 - 2020, thousand rubles.

\begin{tabular}{|l|c|c|c|c|c|c|}
\hline \multirow{2}{*}{ Indicator name } & \multicolumn{5}{|c|}{ Years } & \multirow{2}{*}{$\begin{array}{c}\text { Deviation (+, -) } \\
\text { in relation to 2019 }\end{array}$} \\
\cline { 2 - 7 } & $\mathbf{2 0 1 6}$ & $\mathbf{2 0 1 7}$ & $\mathbf{2 0 1 8}$ & $\mathbf{2 0 1 9}$ & $\mathbf{2 0 2 0}$ & $\mathbf{2 0 2 0}$ \\
\hline $\begin{array}{l}\text { Cash flows from } \\
\text { financial transactions }\end{array}$ & & & & & & \\
\hline Income - total & 139251 & 11000 & 33000 & 33000 & 14300 & -18700 \\
\hline including: & & & & & & -18700 \\
\hline $\begin{array}{l}\text { obtaining loans and } \\
\text { borrowings }\end{array}$ & 72586 & - & 33000 & 33000 & 14300 & - \\
\hline $\begin{array}{l}\text { participants' } \\
\text { contributions }\end{array}$ & - & - & - & - & - & - \\
\hline other supply & 66665 & 11000 & - & - & - & -15641 \\
\hline Payments - total & 166787 & 36970 & 49203 & 36720 & 21079 & - \\
\hline including: & & & & & & - \\
\hline owners in connection & - & - & - & - & - & \\
\hline
\end{tabular}




\begin{tabular}{|c|c|c|c|c|c|c|}
\hline $\begin{array}{l}\text { with the redemption } \\
\text { of their shares }\end{array}$ & & & & & & \\
\hline to pay dividends & - & - & - & - & - & - \\
\hline $\begin{array}{l}\text { in connection with } \\
\text { the redemption of } \\
\text { bills, repayment of } \\
\text { loans and borrowings }\end{array}$ & 158152 & 30172 & 35132 & 35465 & 40480 & 5015 \\
\hline other payments & 8635 & 6798 & 14071 & 1255 & 19401 & 18146 \\
\hline $\begin{array}{l}\text { Balance of cash } \\
\text { flows from financial } \\
\text { transactions }\end{array}$ & -27536 & $\begin{array}{c}- \\
25970\end{array}$ & $\begin{array}{c}- \\
16203\end{array}$ & -3720 & -6779 & -3059 \\
\hline
\end{tabular}

The balance of cash flows from financial activities for the whole period under study is negative, as the amount of payments exceeds the amount of receipts, it can be seen from Table 11 according to the balance of cash flows from financial operations. Special attention should be paid to the fact that the only source of income for the last three years are credits and loans, which in turn can worsen the situation at the enterprise, in case of negative situations.

Thus, summarizing the results of the analysis of the resultant net cash flow and net cash flows from each type of activity of the enterprise, we can characterize the situation related to its cash flows for the analyzed period from 2016 to 2020, in general, as satisfactory.

At the same time, the analysis of the cash flows of the enterprise showed the need to take measures to optimize them. To this end, a number of the following measures should be taken:

- to increase the amount of equity capital by attracting strategic investors;

- increase the amount of equity capital by attracting strategic investors;

- to attract long-term financial loans;

- sell financial investment instruments;

- sell or lease unused items of fixed assets.

To reduce the amount of negative cash flow in the long term, you need to take the following measures:

- to reduce the volume and composition of real investment programs;

- to refuse financial investment;

- to reduce the amount of fixed production costs.

To optimize the surplus cash flow, it is necessary to ensure the growth of its investment activity. For this purpose, it is necessary to increase the volume of reproduction of operational non-current assets; to accelerate the period associated with the development and beginning of implementation of real investment projects; to carry out regional diversification of economic entity's operating activities; to actively form a portfolio of financial investments; to repay long-term financial loans ahead of time.

At the final stage of optimization conditions for maximizing net cash flow of the economic agent are provided. The increase of net cash flow promotes the increase of economic development of enterprise on principles of self-financing, decrease of dependence of enterprise from external sources of formation of financial resources, providing the increase of market cost of enterprise.

Net cash flow of the enterprise can be increased as a result of decrease of the level of variable and fixed costs; implementation of effective pricing and tax policy; optimization of depreciation of fixed assets; sale of non-current assets that are not used in the process of production and financial activity of the enterprise.

The results of cash flow optimization are reflected in the plans for the formation and use of cash. 


\section{Conclusions}

Thus, each economic entity in the process of financial relationships with counterparties carries out non-cash and cash settlements. For cash settlements, enterprises have a cash desk, for non-cash settlements, settlement accounts are opened in banks, which are also used to store their own funds. Cash is an important and necessary resource for efficient and smooth production and financial activities of enterprises. In this regard, each enterprise should ensure thorough control over the availability and movement of funds.

Internal control is one of the tools to increase the efficiency of the company's operations and contribute to the growth of its investment attractiveness. In modern conditions as a result of internal control stakeholders receive information that is necessary to assess the financial condition of the enterprise and subsequent managerial decisions.

For the development of methodological tools of internal control of cash it is proposed to use the developed forms of working documents of internal control. These documents allow to systematize control measures, to evaluate the efficiency of the accounting system organization, to summarize the results of cash flow operations and bank accounts, their appropriateness and validity; to record the revealed violations by the results of cash flow and bank accounts operations inspection. Based on the results of internal control, the company's management makes a decision to improve the efficiency of cash usage based on the creation of a liquidity management system. Before making a decision on improving the efficiency of cash resources use, their composition, dynamics, and structure should be analyzed to identify problematic issues related to their management. As a result of the analysis of cash flows the reasons of shortage or surplus of cash are established, the sources of their receipt and directions of use are determined.

\section{References}

1. A. Diaw, Borsa Istanbul Review 22 (2020) https://doi.org/10.1016/j.bir.2020.09.005

2. A. Marwick, M.M. Hasan, T. Luo, International Review of Financial Analysis 68, 101458 (2020) https://doi.org/10.1016/j.irfa.2020.101458

3. J. Begenau, B. Palazzo, Journal of Financial Economics 139, 697-718 (2021) https://doi.org/10.1016/j.jfineco.2020.09.001

4. M.J. Imhof, S.E. Seavey, Advances in Accounting 41, 74-87 (2018) https://doi.org/10.1016/j.adiac.2018.03.004

5. X. Li, Journal of Accounting and Public Policy 38, 106694 (2019) https://doi.org/10.1016/j.jaccpubpol.2019.106694

6. W. Drobetz, R. Haller, I. Meier, V. Tarhan, The Quarterly Review of Economics and Finance 66, 225-239 (2017) https://doi.org/10.1016/j.qref.2017.03.004

7. A. Zakirova, G. Klychova, G. Ostaev et al, E3S Web of Conferences 164, 10009 (2020) https://doi.org/10.1051/e3sconf /202016410009

8. A. Karpuz, K. Kim, N. Ozkan, Journal of Empirical Finance 59, $52-67$ (2020) https://doi.org/10.1016/j.jempfin.2020.09.004

9. J. Leontieva, E. Zaugarova, G. Klychova, et al, MATEC Web of Conferences 170, 01087 (2018) doi.org/10.1051/matecconf/201817001087

10. T. Sasaki, Pacific-Basin Finance Journal 39, 1-15 https://doi.org/10.1016/j.pacfin.2016.05.002

11. Ch.-Ch. Chang, L.-H. Kao, H.-Y. Chen, Pacific-Basin Finance Journal 51, 47-64 (2018) https://doi.org/10.1016/j.pacfin.2018.06.001 
12. H. Jankensgård, R.M. Moursli, Journal of Banking \& Finance 119, 105916 (2020) https://doi.org/10.1016/j.jbankfin.2020.105916

13. J. Chen, Y.-Ch. Gao, Q. Li, Y. Zeng, Physica A: Statistical Mechanics and its Applications 537, 122571 (2020)

14. J. Mullins, Business Horizons 63, 693-704 (2020) https://doi.org/10.1016/j.bushor.2020.04.003

15. B. von Beschwitz, Journal of Financial Economics 128, 287-319 (2018) https://doi.org/10.1016/j.jfineco.2018.02.009

16. H. Chen, D. Yang, H. Zhou, Journal of Corporate Finance 64, 101695 (2020) https://doi.org/10.1016/j.jcorpfin.2020.101695

17. P. Huang, J. Guo, T. Ma, Y. Zhang, Journal of Banking \& Finance 54, 30-45 (2015)

18. A. Zakirova, G. Klychova, K. Mukhamedzyanov et al, Advances in Intelligent Systems and Computing 1258 AISC, 687-707 (2021) https://doi.org/10.1007/978-3-030-574505_59

19. K. Chalmers, D. Hay, H. Khlif, Journal of Accounting Literature 42, 80-103 (2019) https://doi.org/10.1016/j.acclit.2018.03.002

20. E. Demirakos, The International Journal of Accounting 53, 253-254 (2018) https://doi.org/10.1016/j.intacc.2018.07.001

21. Y.-T. Chang, H. Chen, R.K. Cheng, W. Chi, Journal of Contemporary Accounting \& Economics 15, 1-19 (2019) https://doi.org/10.1016/j.jcae.2018.11.002

22. H. Li, J. Dai, T. Gershberg, M.A. Vasarhely, International Journal of Accounting Information Systems 28, 59-76 (2018) https://doi.org/10.1016/j.accinf.2017.12.005

23. G. Klychova, A. Zakirova, I. Gimadiev et al, E3S Web of Conferences 110, 02015 (2019) https://doi.org/10.1051/e3sconf /20191100

24. X.-d. Ji, W. Lu, W. Qu, Journal of Contemporary Accounting \& Economics 14, 266287 (2018) https://doi.org/10.1016/j.jcae.2018.07.002

25. G. Klychova, A. Zakirova, S. Alibekov, et al, Advances in Intelligent Systems and Computing 1258 AISC, 669-686 (2021) https://doi.org/10.1007/978-3-030-574505_58

26. E. Demirakos, The International Journal of Accounting 53, 253-254 (2018) https://doi.org/10.1016/j.intacc.2018.07.001

27. G.S. Klychova, B.G. Ziganshin, A.R. Zakirova et al, Journal of Engineering and Applied Sciences 12, 4958-4965 (2017) DOI: 10.36478/jeasci.2017.4958.4965

28. P. Clarkson, R. Gao, K. Herbohn, Journal of Contemporary Accounting \& Economics 16, 100201 (2020) https://doi.org/10.1016/j.jcae.2020.100201

29. G. Klychova, A. Zakirova, K. Pinina et al, E3S Web of Conferences 110, 02075 (2019) https://doi.org/10.1051/e3sconf/201911002075 